\title{
Effect of Mineral and Nano Nitrogen Fertilizers on Yield and Yield Components of Some Yellow Maize Hybrids \\ El-Gewely, Fathia M. M. ${ }^{1}$; N. Kh. B. El-Gizawy ${ }^{1}$; I. M. Fared ${ }^{2}$ and S. A. S. Mehasen, ${ }^{1 *}$ \\ ${ }^{1}$ Agronomy Dept., Fac. of Agric., Moshtohor, Benha Univ., Egypt. \\ 2 Soil \& Water Dept., Fac. of Agric., Moshtohor, Benha Univ., Egypt \\ *Corresponding author: Sadiek Abdelaziz Sadiek Mehasen, Head Department of Agronomy, Faculty of Agriculture at Moshtohor, Benha University, Egypt. PO Box 13736.
}

\begin{abstract}
Two field experiments were conducted at the Experiment and Research Center, Fac. Agric., Moshtohor, Benha Univ., during 2018 and 2019 summer seasons. The aim of this was to study response of three yellow maize hybrids (SC 2055, SC 176 and SC P3737) to three $\mathrm{N}$ fertilizer rates (60, 90 and $120 \mathrm{~kg} \mathrm{~N}^{-1}$ fed and two Nano-N foliar applications (Without and Nano foliar applications). The experimental design was randomized complete block design (RCBD) using split split-plots arrangement with three replications. The yellow maize hybrids, $\mathrm{N}$ fertilizer levels and Nano-N foliar applications were arranged at random in the main plots, sub- plots and sub sub-plots, respectively. Single Cross P3737 was significantly earlier than the other hybrids regarding $50 \%$ tasseling and silking. Also, SC P3737 was superior to the other two hybrids in most of the studied traits. The highest values of plant height, ear length, ear diameter, No. grains row $^{-1}$, ear weight, ear grains weight, 100-grain weight, Forge yield $\mathrm{fed}^{-1}$ and grain yield fed ${ }^{-1}$ were obtained with fertilizer level of $120 \mathrm{~N} \mathrm{fed}^{-1}$. On the other hand, the earliest tasseling and silking were recorded with $60 \mathrm{~kg} \mathrm{~N} \mathrm{fed}^{-1}$. Nano foliar application gave the greatest of all grain yield and attributes of yellow maize hybrids as compared with untreated. It could be concluded that under the conditions of the experiment, planting SC P3737 under 90 or $120 \mathrm{~N} \mathrm{fed}^{-1}$ and nano foliar application is recommended.
\end{abstract}

Key Words: Yellow maize hybrids, $N$ application rates, $N$ Nano chitosan, growth, Yield and yield components.

\section{Introduction}

Maize (Zea mays L.) is one of the most important strategic crops in Egypt and the world, and it ranks third order after wheat and rice crops in the cultivated area and productivity. The Egyptian policy aims to increase yellow maize production to face the large demand in order to minimize its imports through breeding for high yielding hybrids. This could be achieved by using high yielding hybrids and fertilization. The productivity of grain crops, including maize, is greatly influenced by the availability and abundance of the essential nutrients $\mathrm{N}$ necessary for plant growth and production.

In this connection, maize hybrids differ in grain yield and yield attributes as reported by Mehasen and Ahmed (2009); Mehasen and El-Gizawy (2010); ElBadawy and Mehasen (2011), Kandil, (2013), Eivazi and Habibi (2013), Gomaa, et al, (2017), Nassar, et al, (2017), Awdalla, et al (2018), AL-Shumary et al, (2019), Khalil, et al, (2019), and Afolabi, et al, (2020).

Several researchers reported that nitrogen is the most limiting factor to increase maize grain yield and its components. They found that plant height, ear length, No. of grains row $^{-1}$, ear weight, ear grain weight, 100-grain weight, forge yield $\mathrm{fed}^{-1}$ and grain yield $\mathrm{fed}^{-1}$ of maize were increased by increasing nitrogen level (Akmal et al, 2010, Ali et al, 2011; Moraditochaee et al, 2012, Kandil, 2013, Sime and
Aune, 2014, Bilal, et al, 2016, Nassar, et al, 2017, Khalil, et al, 2019 and Afolabi, et al, 2020).

Therefore, it is necessary to use the best modern techniques to supply the plant with nutrients. These techniques include using nano fertilizers, balanced $\mathrm{N}$ nano fertilizer and adding them either by spraying the total vegetative. Nanotechnology can provide the solution to increasing the value of agricultural products and overcome environmental problems by using fertilizers with nanoparticles with sizes (1-100 nanometers). Thus we can control the release of mineral elements added as fertilizers, the basis of the work of nano fertilizers is the rapid supply of nutrients and increase the duration of the fertilizer effect. Consequently, many workers came to reported that nano fertilizers is the most limiting factor to increase maize grain yield and yield attributes (Fan et al, 2012, Kandil 2013, Awadalla and Morsy 2016, Ahmad et al, 2018 and Emara et al, 2018, Al-Saray and AlRubaee, 2019, AL-Shumary et al, 2019, Khalil et al, 2019 and AL-Gym and Al-Asady, 2020).

The present investigation aimed to study the effect of mineral and nano nitrogen fertilizers on yield and its attributes for yellow maize hybrids grown on a clay soil in Kalubia Governorate.

\section{Materials and Methods}

Two field experiments were carried out in the Experimental Field of the Faculty of Agriculture at 
Mashtohor, Benha Univ., during 2018 and 2019 seasons, to study the effect of three $\mathrm{N}$ fertilizer levels $\left(60,90\right.$ and $\left.120 \mathrm{~kg} \mathrm{~N} \mathrm{fed}^{-1}\right)$ and two Nano-N foliar applications (Without and Nano foliar applications) on yield and yield attributes for three yellow maize hybrids (SC 2055, SC 176 and SC P3737). Maize hybrids namely SC 2055 was developed by haytic Company, SC 176 was developed by maize Depart. Research, ARC and SC P3737 was developed by Pioneer Company. The soil was clay in texture with a $\mathrm{PH}$ value of 7.95 and 7.92 and an organic matter content of 1.72 and $1.73 \%$ and available $\mathrm{N}$ of 51 and $52 \mathrm{ppm}$ during the first and second seasons, respectively. The experimental sites were preceded by wheat in the two seasons.

The experimental design was randomized complete block design (RCBD) using split split-plots arrangement with three replications. The three yellow maize hybrids were arranged at random in the main plots, the sub- plots were assigned random by to three $\mathrm{N}$ fertilizer levels and the two Nano-N foliar applications were arranged random by in the sub subplots. The sub sub-plot area was $10.5 \mathrm{~m}^{2}$ (1/400 fed) consisting of 5 ridges, $3.5 \mathrm{~m}$ long and $70 \mathrm{~cm}$ width while, the distance between plants was $25 \mathrm{~cm}$. Planting date was May2 $7^{\text {th }}$ and $24^{\text {th }}$ in 2018 and 2019 seasons, respectively. Nitrogen levels in the form of urea $46 \% \mathrm{~N}$ were applied in two split applications before the first and second irrigations. Nano Fab Technology was used as Nano fertilizer obtained from the company. It contained N (5\%) and inert ingredients (95\%). Physical and chemical properties are colorless, liquid and urea nitrogen source. The average of nanoparticles was $15.02 \mathrm{~g} \cdot \mathrm{mol}^{-1}$. Maize plants were sprayed twice with the aqueous solution of nano-N applications (Chitosan) at $30^{\text {th }}$ and $45^{\text {th }}$ days after planting, while control plants were sprayed with tap water. All other cultural practices were applied as recommended for this region in both seasons.

Days to $50 \%$ tasseling and silking were recorded. Plant height $(\mathrm{cm})$ was measured after 85 days from planting as an average of 10 plants. At harvest, the following data were recorded on 10 individual plants at random: Ear length $(\mathrm{cm})$, No. grains row $^{-1}$, ear weight $(\mathrm{g})$, grains ear weight $(\mathrm{g})$ and 100 -grain weight $(\mathrm{g})$. Forge yield (ton fed ${ }^{-1}$ ) and grain yield $\left(\mathrm{kg} \mathrm{fed}^{-1}\right)$ on whole plot basis and adjusted to $15.5 \%$ grain moisture content.

Analysis of variance was done for the data of each season by Snedecor and Cochran (1980) using the MSTAT-C Statistical Software package (Michigan State University, 1983). Mean comparisons were done by least significant difference (LSD) test at the 0.05 level of significance.

\section{Results and Discussion}

\section{-Effect of maize hybrids:}

The results reported in Table 1 indicate clearly that, there were significant differences among yellow maize hybrids in all studied traits in the first and second seasons. SC P3737 hybrid gave the highest values of plant height, ear length, No. grains row $^{-1}$, ear weight, grains ear weight, 100-grain weight, forge yield fed $^{-}$ ${ }^{1}$ and grain yield fed ${ }^{-1}$ compared with the other hybrids in both seasons. In addition, SC P3737 hybrid was significantly the earliest in tasseling and silking date compared with the other hybrids in the first and second seasons except tasseling date in the second season. Such results could be attributed to differences in the genetic constitution of the tested hybrids. The increase in grain yield $\mathrm{fed}^{-1}$ might be due to superiority in ear length, No. grains row $^{-1}$, ear weight, grains ear weight, and 100-grain weight grain as shown in Table (1). These results are in harmony with those obtained by Mehasen and Ahmed (2009); Mehasen and ElGizawy (2010); El-Badawy and Mehasen (2011), Kandil, (2013), Eivazi and Habibi (2013), Gomaa, et al, (2017), Nassar, et al, (2017), Awdalla, et al (2018), Khalil, et al, (2019), and Afolabi, et al, (2020).

Table 1. Yield and its attributes of yellow maize as affected by hybrids in 2018 and 2019 seasons

\begin{tabular}{|c|c|c|c|c|c|c|c|c|}
\hline \multirow[b]{2}{*}{ Characters } & \multicolumn{3}{|c|}{2018 season } & \multirow{2}{*}{$\begin{array}{c}\text { LSD } \\
\text { at } \\
\mathbf{5 \%}\end{array}$} & \multicolumn{3}{|c|}{2019 season } & \multirow{2}{*}{$\begin{array}{c}\text { LSD } \\
\text { at } \\
\mathbf{5 \%}\end{array}$} \\
\hline & $\begin{array}{c}\text { SC } \\
2055\end{array}$ & $\begin{array}{l}\mathrm{SC} \\
176\end{array}$ & $\begin{array}{c}\text { SC } \\
\text { P3737 }\end{array}$ & & $\begin{array}{r}\text { SC } \\
2055\end{array}$ & $\begin{array}{c}\mathrm{SC} \\
176\end{array}$ & $\begin{array}{c}\text { SC } \\
\text { P3737 }\end{array}$ & \\
\hline No. days to $50 \%$ tasseling & 55.22 & $\mathbf{5 8 . 8 8}$ & 51.44 & 0.73 & $\mathbf{5 4 . 0 0}$ & 57.27 & 49.88 & 3.31 \\
\hline No. days to $50 \%$ silking & $\mathbf{5 8 . 0 5}$ & 61.55 & 54.66 & 1.48 & $\mathbf{5 7 . 1 6}$ & 60.66 & 53.38 & 0.70 \\
\hline Plant height (cm) & 226.3 & 190.9 & 235.9 & 16.5 & 280.1 & 263.2 & 281.9 & 6.1 \\
\hline Ear length $(\mathrm{cm})$ & 18.68 & 16.30 & 19.72 & NS & 19.17 & 18.31 & 21.12 & NS \\
\hline No. grains row ${ }^{-1}$ & 38.76 & 33.58 & 43.80 & 1.13 & 38.92 & 36.00 & 46.05 & 4.93 \\
\hline Ear weight (g) & 209.33 & 193.72 & 216.83 & 5.57 & 213.38 & 196.50 & 219.38 & 4.91 \\
\hline Grains ear weight (g) & 161.94 & 148.00 & 177.44 & 5.26 & 166.38 & 150.94 & 177.83 & 3.61 \\
\hline 100-grain weight (g) & 34.44 & 32.50 & 39.44 & 1.71 & 36.55 & 34.00 & 41.11 & 1.70 \\
\hline Forge yield (ton fed ${ }^{-1}$ ) & 24.44 & 20.50 & 26.22 & 1.08 & 25.77 & 21.50 & 27.00 & 1.74 \\
\hline Grain yield $\left(\mathrm{kg} \mathrm{fed}^{-1}\right)$ & 2586.11 & 2162.8 & 2763.9 & 54.6 & 2661.7 & 2259.4 & 2822.8 & 81.1 \\
\hline
\end{tabular}


NS=No significance

\section{-Effect of Nitrogen Fertilizer:}

Data in Table 2 show that mean values of yield and yield attributes in both seasons were significantly increased by increasing $\mathrm{N}$ levels up to $120 \mathrm{~kg} \mathrm{~N} \mathrm{fed}^{-1}$. The highest values of tasseling and silking date, plant height, ear length, No. grains row ${ }^{-1}$, ear weight, grains ear weight, 100-grain weight, forge yield $\mathrm{fed}^{-1}$ and grain yield $\mathrm{fed}^{-1}$ in the first and second seasons were obtained with fertilizer level $120 \mathrm{~kg} \mathrm{~N} \mathrm{fed}^{-1}$. There were significant responses to nitrogen with characters asserting the vital need for $\mathrm{N}$ application to maize production in this soil. The increases in yield and components may be due to the increases in the growth characters and indirectly affected by $\mathrm{N}$ general functions in plant. Furthermore, the increase in grain yield/fed is attributed mainly to the increases in yield components. The adding of nitrogen of great importance in increasing vegetative growth and thus increasing the activity of photosynthesis and thus the accumulation of dry matter in the grain and its role in prolonging the period of full-grain and delaying senescence of leaves (Otung, 2014). The results of this experiment agree with those obtained by Akmal $\boldsymbol{e t}$ al, 2010, Ali et al, 2011; Moraditochaee et al, 2012, Kandil, 2013, Sime and Aune, 2014, Bilal, et al, 2016, Nassar, et al, 2017, Khalil, et al, 2019 and Afolabi, et al, 2020.

Table 2. Yield and its attributes of yellow maize as affected by N fertilizer rates in 2018 and 2019 seasons

\begin{tabular}{|c|c|c|c|c|c|c|c|c|}
\hline \multirow[b]{2}{*}{ Characters } & \multicolumn{3}{|c|}{2018 season } & \multirow{2}{*}{$\begin{array}{l}\text { L.S.D } \\
\text { at 5\% }\end{array}$} & \multicolumn{3}{|c|}{2019 season } & \multirow{2}{*}{$\begin{array}{l}\text { L.S.D } \\
\text { at 5\% }\end{array}$} \\
\hline & 60 & 90 & 120 & & 60 & 90 & 120 & \\
\hline No. days to $50 \%$ tasseling & $\mathbf{5 4 . 0 5}$ & $\mathbf{5 5 . 0 0}$ & 56.50 & 0.54 & $\mathbf{5 3 . 0 0}$ & $\mathbf{5 3 . 9 4}$ & 54.22 & NS \\
\hline No. days to $50 \%$ silking & 56.55 & $\mathbf{5 7 . 7 7}$ & 59.94 & 1.38 & 55.38 & 57.27 & 58.55 & 1.58 \\
\hline Plant height (cm) & 208.42 & 218.94 & 225.78 & 7.67 & 266.50 & 277.50 & 281.27 & 4.69 \\
\hline Ear length (cm) & 17.19 & 18.54 & 18.97 & 0.62 & 18.95 & 19.45 & 20.21 & NS \\
\hline No. grains row ${ }^{-1}$ & 36.57 & 38.95 & 40.61 & 1.20 & 37.26 & 41.25 & 42.45 & 2.25 \\
\hline Ear weight (g) & 189.11 & 208.88 & 221.88 & 3.59 & 193.27 & 209.94 & 226.05 & 2.25 \\
\hline Grains ear weight (g) & 145.33 & 164.88 & 177.16 & 5.71 & 146.38 & 165.66 & 183.11 & 3.18 \\
\hline 100-grain weight (g) & 30.77 & 35.66 & 39.94 & 1.45 & 32.55 & 37.61 & 41.50 & 1.89 \\
\hline Forge yield (ton fed ${ }^{-1}$ ) & 21.16 & 23.94 & 23.94 & 1.04 & 22.27 & 24.88 & 27.11 & 1.10 \\
\hline Grain yield $\left(\mathrm{kg} \mathrm{fed}^{-1}\right)$ & 1982.2 & 2558.3 & 2972.2 & 39.6 & 2042.8 & 2656.7 & 3044.4 & 64.8 \\
\hline
\end{tabular}

NS=No significance

-Effect of Nano foliar application:

Results in Table 3 show in general that nearly all maize characters were significantly affect by nano foliar application treatment in both seasons except No. days to $50 \%$ tasseling and 100-grain weight in the second season. However, nano foliar application treatment increased significantly in silking date, plant height, ear length, No. grains row $^{-1}$, ear weight, grains ear weight, 100-grain weight, forge yield $\mathrm{fed}^{-1}$ and grain yield $\mathrm{fed}^{-1}$ in the two seasons, tasseling date and 100- grain weight in the first season only. The following sequence of treatments (nano foliar application treatment) was displayed with respect to yield and yield attributes. The results of this experiment agreed with (Fan et al, 2012, Kandil 2013, Awadalla and Morsy 2016, Ahmad et al, 2018 and Emara et al, 2018, Al-Saray and Al-Rubaee, 2019, AL-Shumary et al, 2019, Khalil et al, 2019 and AL-Gym and AlAsady, 2020).

Table 3. Yield and its attributes of yellow maize as affected by Nano-N foliar application in 2018 and 2019 seasons

\begin{tabular}{|c|c|c|c|c|c|c|}
\hline \multirow[b]{2}{*}{ Characters } & \multicolumn{2}{|c|}{2018 season } & \multirow{2}{*}{$\begin{array}{c}\text { L.S.D at } \\
\mathbf{5 \%}\end{array}$} & \multicolumn{2}{|c|}{2019 season } & \multirow{2}{*}{$\begin{array}{c}\text { L.S.D at } \\
\mathbf{5 \%}\end{array}$} \\
\hline & Without & Nano & & Without & Nano & \\
\hline No. days to $50 \%$ tasseling & 54.92 & 55.44 & 0.45 & 53.96 & 53.48 & NS \\
\hline No. days to $50 \%$ silking & $\mathbf{5 7 . 5 5}$ & 58.63 & 0.77 & 56.51 & 57.63 & 0.14 \\
\hline Plant height (cm) & 207.62 & 227.81 & 6.87 & 265.18 & 285.00 & 5.75 \\
\hline Ear length (cm) & 17.52 & 18.95 & 0.30 & 19.00 & 20.07 & 0.88 \\
\hline No. grains row ${ }^{-1}$ & 37.11 & 40.32 & 1.31 & 38.09 & 42.55 & 1.42 \\
\hline Ear weight (g) & 203.40 & 209.85 & 1.68 & 205.85 & 213.66 & 1.42 \\
\hline Grains ear weight (g) & 157.81 & 167.11 & 4.10 & 160.55 & 169.55 & 2.20 \\
\hline 100-grain weight (g) & $\mathbf{3 4 . 8 5}$ & 36.07 & 0.65 & $\mathbf{3 6 . 8 5}$ & $\mathbf{3 7 . 5 9}$ & NS \\
\hline Forge yield (ton fed ${ }^{-1}$ ) & 23.44 & 24.00 & 0.46 & 24.44 & 25.07 & 0.41 \\
\hline Grain yield $\left(\mathrm{kg} \mathrm{fed}^{-1}\right)$ & 2446.7 & 2561.9 & 34.2 & 2525.2 & 2637.4 & 35.7 \\
\hline
\end{tabular}


$\mathrm{NS}=$ No significance

- Effect of the interactions:

The significant interactions among yellow maize hybrids, $\mathrm{N}$ fertilizer levels and nano foliar application on the traits are shown in Tables $4 a, 4 b, 4 c$ and 5.

The combination of yellow maize hybrids with $\mathrm{N}$ fertilizer levels indicated that the heaviest values were obtained by SC P3737 hybrid with $120 \mathrm{~kg} \mathrm{~N}^{\mathrm{N}} \mathrm{fe}^{-1}$ for grain yield $\mathrm{fed}^{-1}$, in both seasons (Table $4 \mathrm{a}$ ). On the other hand, the lowest values in grain yield $\mathrm{fed}^{-1}$ were obtained by SC 176 hybrid with $60 \mathrm{~kg} \mathrm{~N}^{-1} \mathrm{fed}^{-1}$ in the first and second seasons.

Table 4a. Effect of the interaction between of yellow maize hybrids and $\mathrm{N}$ fertilizer rates on grain yield $\mathrm{kg}$ fed ${ }^{-1}$ in 2018 and 2019 seasons

\begin{tabular}{|c|c|c|c|c|c|c|}
\hline \multirow{3}{*}{$\begin{array}{c}\mathbf{N} \text { fertilizer } \\
\text { rates }\end{array}$} & \multicolumn{3}{|c|}{2018 season } & \multicolumn{3}{|c|}{2019 season } \\
\hline & \multicolumn{6}{|c|}{ yellow maize hybrids } \\
\hline & SC 2055 & SC 176 & SC P3737 & SC 2055 & SC 176 & SC P3737 \\
\hline $60 \mathrm{~kg} \mathrm{fed}^{-1}$ & 2066.66 & 1738.33 & 2141.66 & 2141.66 & 1811.66 & 2175.00 \\
\hline $90 \mathrm{~kg} \mathrm{fed}^{-1}$ & 2558.33 & 2233.33 & 2883.33 & 2141.66 & 2358.33 & 2951.66 \\
\hline $120 \mathrm{~kg} \mathrm{fed}^{-1}$ & 3133.33 & 2883.33 & 3266.66 & 3183.33 & 2608.33 & 3341.66 \\
\hline L.S.D at $5 \%$ & & 84.65 & & & 112.4 & \\
\hline
\end{tabular}

The combination of yellow maize hybrids with nano foliar application showed that the highest values were obtained by SC P3737 hybrid with nano foliar application treatment for ear length in both seasons are shown Table (4b). On the other hand, SC 176 hybrid with zero nano foliar application treatment gave the lowest values in ear length in both seasons.

The data presented in Table (4c) demonstrated that maximum values were gained in ear length $60 \mathrm{~kg} \mathrm{~N}$ $\mathrm{fed}^{-1}$ application with nano foliar application treatment in the first season. The highest values of grain yield (3000.00 and $3088.88 \mathrm{~kg} \mathrm{fed}^{-1}$ ) were obtained from application $120 \mathrm{~kg} \mathrm{~N}^{-1} \mathrm{f}^{-1}$ with nano foliar application treatment in the first and second seasons, whereas the lowest values in these traits were exhibited by $60 \mathrm{~kg} \mathrm{~N}$ $\mathrm{fed}^{-1}$ with zero nano foliar application treatment in the first and second seasons.

Table 4b. Effect of the interaction between yellow maize hybrids and Nano $\mathrm{N}$ foliar application on ear length (cm) in 2018 and 2019 seasons

\begin{tabular}{ccccccc}
\hline Nano-N foliar $\begin{array}{c}\text { 2018 season } \\
\text { application }\end{array}$ & \multicolumn{3}{c}{ yellow maize hybrids } \\
\cline { 2 - 7 } & SC 2055 & SC 176 & SC P3737 & SC 2055 & SC 176 & SC P3737 \\
\cline { 2 - 7 } & 17.93 & 15.36 & 19.26 & 18.95 & 17.56 & 20.48 \\
Without & 19.43 & 17.24 & 20.17 & 19.40 & 19.05 & 21.77 \\
Nano & & 0.53 & & NS & \\
\hline L.S.D at 5\% & NS=No significance & &
\end{tabular}

Table 4c. Effect of the interaction between $\mathrm{N}$ fertilizer rates and Nano $\mathrm{N}$ foliar application on ear length (cm) and grain yield $\mathrm{kg} \mathrm{fed}^{-1}$ in 2018 and 2019 seasons

\begin{tabular}{|c|c|c|c|c|c|c|}
\hline \multirow{3}{*}{$\begin{array}{l}\text { Nano-N foliar } \\
\text { application }\end{array}$} & \multicolumn{3}{|c|}{2018 season } & \multicolumn{3}{|c|}{2019 season } \\
\hline & \multicolumn{6}{|c|}{$\mathrm{N}$ fertilizer rates $\mathrm{kg}$ fed $^{-1}$} \\
\hline & 60 & 90 & 120 & 60 & 90 & 120 \\
\hline \multicolumn{7}{|c|}{ Ear length $(\mathrm{cm})$} \\
\hline Without & 16.22 & $\mathbf{1 7 . 5 1}$ & 18.83 & 17.98 & 19.16 & 19.85 \\
\hline Nano & 18.16 & 19.57 & 19.11 & 19.91 & 19.74 & 20.56 \\
\hline L.S.D at $5 \%$ & & 0.52 & & & NS & \\
\hline \multicolumn{7}{|c|}{ Grain yield kg fed $^{-1}$} \\
\hline Without & $\overline{1934.44}$ & 2461.11 & 2944.44 & 2007.77 & 2567.77 & 3000.00 \\
\hline Nano & 2030.00 & 2655.55 & 3000.00 & 2077.77 & 2745.55 & 3088.88 \\
\hline L.S.D at 5\% & & 59.32 & & & 61.85 & \\
\hline
\end{tabular}

NS=No significance 
The highest values of ear length $(20.36 \mathrm{~cm})$ were obtained from SC P3737 hybrid $+60 \mathrm{~kg} \mathrm{~N}$ fed $^{-1}$ application + nano foliar application in the first season. On the other hand, SC 176 hybrid under zero $\mathrm{N} \mathrm{kg} \mathrm{fed}^{-1}$ with zero nano foliar application treatment gave the lowest value in ear length $(14.30 \mathrm{~cm})$ in the first season. It could be concluded that under the conditions of the experiment planting SC P3737 hybrid under application of 90 or $120 \mathrm{~kg} \mathrm{~N}^{-1}$ application with nano foliar application treatment is recommended.

Table 5. Effect of the interaction between yellow maize hybrids, $\mathrm{N}$ fertilizer rates and Nano $\mathrm{N}$ foliar application on ear length (cm) in 2018 and 2019 seasons

\begin{tabular}{|c|c|c|c|c|c|c|c|}
\hline \multirow{3}{*}{$\begin{array}{c} \\
\text { fertilizer } \\
\text { rates }\end{array}$} & \multirow{3}{*}{$\begin{array}{c}\begin{array}{c}\text { Nano-N } \\
\text { foliar } \\
\text { application }\end{array} \\
\end{array}$} & \multicolumn{3}{|c|}{2018 season } & \multicolumn{3}{|c|}{2019 season } \\
\hline & & \multicolumn{6}{|c|}{ yellow maize hybrids } \\
\hline & & SC 2055 & SC 176 & SC P3737 & SC 2055 & SC 176 & SC P3737 \\
\hline 60 & Without & 16.46 & 14.30 & 17.90 & 17.63 & 17.03 & 19.30 \\
\hline $\mathrm{kg} \mathrm{fed}^{-1}$ & Nano & 18.66 & 15.86 & 19.96 & 19.90 & 18.70 & 21.14 \\
\hline \multirow{2}{*}{$\begin{array}{c}90 \\
\mathrm{~kg} \mathrm{fed}^{-1}\end{array}$} & Without & 17.80 & 14.93 & 19.80 & 19.23 & 17.83 & 20.42 \\
\hline & Nano & 19.90 & 18.46 & 20.36 & 17.76 & 19.20 & 22.26 \\
\hline \multirow{2}{*}{$\begin{array}{c}120 \\
\mathrm{~kg} \mathrm{fed}^{-1}\end{array}$} & Without & 19.53 & 16.86 & 20.10 & 20.00 & 17.83 & 21.73 \\
\hline & Nano & 19.73 & 17.40 & 20.20 & 20.53 & 19.26 & 21.90 \\
\hline L.S.D at 5\% & & & 0.91 & & & NS & \\
\hline
\end{tabular}

NS=No significance

\section{References}

Afolabi, M. S., M. A. Murtadha, W. A. Lamidi, J. A. Abdul Waheed, A. E Salami and O. B. Bello, 2020. Evaluation of yield and yield components of low $\mathrm{n}$ maize (Zea mays L.) varieties under low and high nitrogen conditions. Afr. J. Agric. Res., 15(1): 66-72.

Ahmad, S., A.A. Khan, M. Kamran, I. Ahmad, S. Ali and S. Fahad 2018. Response of maize cultivars to various nitrogen levels. Eur. Exp. Biol, $8(1): 1-4$.

Akmal, M., H.U. Rehman, F.M. Asim and H. Akbar, 2010. Response of maize varieties to nitrogen application for leaf area profile, crop growth, yield and yield components. Pak. J. Bot., 42(3): 1941-1947.

AL-Gym A. J. K. and M. H. S. Al-Asady, 2020. Effect of the method and level of adding NPK nanoparticles and mineral fertilizers on the growth and yield of yellow corn and the content of mineral nutrient of some plant parts. Plant Archives, 20 (1): $38-43$.

Ali, K., F. Munsif, M. Zubair, H. Akbar, Z. Hussain, M. Shahid, I. U. Din and N. Khan, 2011. Management of organic and inorganic nitrogen for different maize varieties. Sarhad $J$. Agric., 27(4):525-529.

Al-Saray M. K. S. and F. A. H. Al-Rubaee, 2019. Effect of nano-nitrogen and manufacture organic fertilizer as supplementary fertilizer in the yield and its component for three synthetics of maize (Zea mays L.). Plant Archives 19(2): 1473-1479.

AL-Shumary, Anhar M. J., H. A. Ali and S. A. Alabdulla, 2019. Effect of spraying concentrations of integrated nano-fertilizer on growth and yield of genotypes of corn (Zea mays L.). Muthanna J. of Agric. Sci, 7(2):114-121.

Awadalla, A. and A.S.M. Morsy, 2016. Response of some yellow maize crosses to $\mathrm{N}$-fertilizer rates and plant densities at Toshka Region. Egypt. J. Agron. 38(3), 337-354.

Awdalla, H.A., Gh. F. H. El-Sheref and A.M. Abd El-Hafeez, 2018. Response of some maize hybrids (Zea mays L.) to NPK fertilization. The $15^{\text {th }}$ Inter. Conf. of Crop Sci., Ain Shams Univ., Cairo, Egypt, Oct., pp. 1-70.

Bilal, M., A. Ahmad, A. Shan and A. Jalal, 2016. Enhancing maize yield through integration of organic and inorganic nitrogen fertilizers. Int. J. Agric. Environ. Res., 2(2): 153-161.

Eivazi, A. and F. Habibi, 2013. Evaluation of nitrogen use efficiency in corn (Zea mays L.) varieties. World Appl. Sci. J., 21 (1):63-68.

El-Badawy, M.El. M. and S.A.S. Mehasen, 2011. Multivariate Analysis for Yield and Its Components in Maize under Zinc and Nitrogen Fertilization Levels. Aust. Basic. J. \& Appl. Sci., 5(12): 30083015.

Emara, M.A.A., Hamoda, S.A.F. and Maha, M.A. Hamad, 2018. Effect of nano-fertilizer and Nfertilization levels on productivity Egyptian cot-ton under different sowing dates. The $15^{\text {th }}$ In-ter. Conf. of Crop Sci., Ain Shams Univ., Cairo, Egypt, Oct., pp. 125-137.

Fan, L., Y. Wang, X. Shao, Y. Geng, Z. Wang, Y. Ma and J. Liu, 2012. Effects of combined nitrogen fertilizer and nano-carbon application on yield and nitrogen use of rice grown on saline-alkali soil. $J$. Food, Agric. \& Environ., 10(1), 558-562. 
Gomaa, M.A.; F.I. Radwan; E.E. Kandil and D.H.H. Al-Challabi, 2017. Comparison of some new maize hybrids response to mineral fertilization and some nanofertilizers. Alex. Sci. Exch. J., 38(3): 506-514.

Kandil, E.E.E., 2013. Response of some maize hybrids (Zea mays L.) to different levels of nitrogenous fertilization. J. Appl. Sci. Res., 9 (3):1902-1908.

Khalil M.H., A.F. Abou-Hadid, R.Th. Abdrabou, S.H. Abd Al-halim and M.Sh. Abd El-Maaboud, 2019. Response of two maize cultivars (Zea mays L.) to organic manur and mineral nano nitrogen fertilizer under Siwa Oasis conditions. AUJAS, Ain Shams Univ., Cairo, Egypt, Special Issue, 27(1):299-312.

Mehasen, S.A.S. and M.A. Ahmed, 2009. Improvement of corn productivity by bacterial inoculation, $\mathrm{N}$ mineral and organic fertilization. Fayoum J. Agric. Res. \& Dev., 23 (1B):66-75.

Mehasen, S.A.S. and N.Kh. El-Gizawy, 2010. Evaluation of some maize varieties to soil moisture stress. Proc. $12^{\text {th }}$ conf. Agron., Suez canal Univ., EL-Aresh, Egypt,26-38 (Sept.,).
Michigan State University, 1983. MSTAT-C: Microcomputer Statistical Program, Version 2.0. Michigan State University, East Lansing.

Moraditochaee, M., M.K. Motamed, E. Azarpour, R.K. Danesh and H.R. Bozorgi, 2012. Effects of nitrogen fertilizer and plant density Management in corn farming. ARPN J. of Agric. and Biol. Sci., 7(2): 133-137.

Nassar, M. A. A., I. F. Rehab, E. E. Kandil, A.A.A. El-Banna, and K. A.M.M. Nasr, 2017. Response of Some New Hybrids of Maize to Mineral and Organic Fertilization in Reclaime Soil. J. $A d v$. Agric. Res. (Fac. Agric. Saba Basha), 22 (2):360372 .

Otung, I.A., 2014. Evaluation of six Chinese maize (Zea mays L.) varieties in the humid tropical environment of Calabar, south-east, Nigeria. Global J. Agric. Res., 2(3):10-16.

Sime, G. and J.B. Aune, 2014. Maize response to fertilizer dosing at three sites in the central rift valley of Ethiopia. Agron., 4:436-451.

Snedecor, G. W. and W. G. Cochran, 1980. Statistical Methods, $7^{\text {th }}$ Ed., Iowa State Univ. Press, Ames, Iowa, USA.

$$
\begin{aligned}
& \text { تأثير التمسيد النيتروجيني المعني والتانو علي المحصول ومكوناتة لبعض هجن الأرة الشامية الصفراء } \\
& \text { صديق عبد العزيز صديق محيسن } 1 \text { ، ناصر خميس بركات الجيزاوي } 1 \text { ، إيهاب محمد فريد² وفتحية مصطفي محمد الجويلي } 1 \\
& \text { 1قسم المحاصيل - كلية الزراعة بمشتهز - جامعة بنها } \\
& \text { 2قتم الأراضي - كلية الزراعة بمشتهر - جامعة بنها }
\end{aligned}
$$

أجريت تجربتان حقليتان بمركز البحوث والتجارب بكلية الزراعة بمشتهر - جامعة بنها خلا موسمى الصيف 2018 و 2019 م لدراسة إستجابة ثلاث هجن فردية للذرة الثامية الصفراء (هايتك 2055 ، 176 ، بايونير P3737) لثلاث معدلات من التسميد النيتروجيني (60 ، 90 ، 120 ( 120 كجم ن ف إن) ومعدلين من التسميد النبتروجيني بتقنية النانو (صفر و3 مليلتز لتر -1) ) علي المحصول وبعض مكوناتة. تم استخدام تصميم القطاعات كاملة العشوائية فى توزيع القطع المنشقة مرتين باستخدام ثلاث مكررات. ونم وضع الهجن الصفراء فى القطع الرئيسية ومستوبات التسميد النيتروجينى فى القطع الثقية ومعاملات النانو فى القطع تحت الثقية. سجل الهجين بايونير P3737 أعلى منوسطات و بفرق معنوي فى معظم الصفات المدروسة مقارنة بالهجن الأخرى لكلا موسمي الزراعة. وأيضا سجل نفس الهجين أقل عدد أيام من الزراعة حتي طرد النورة المذكرة والمؤنثة

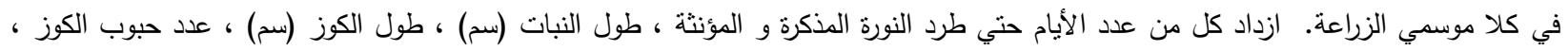

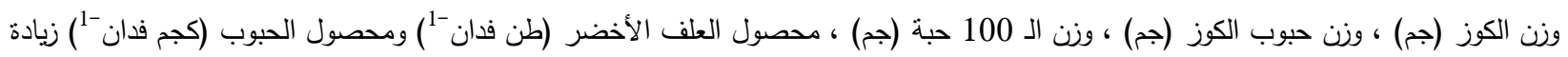
معنوية بزيادة معدل النسميد النيتروجيني حتي 120كجم ن فدان-1 في كل من موسمي الزراعة الأول والثاني. كانت هناك زيادة معنوية فى معظم

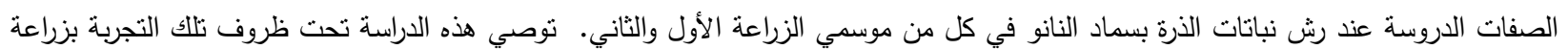
الهجين بايونير 3737 دع التسميد النيتروجين بمعدل 90 أو 120 كجم ن فدان -1 ورش نباتات الذرة بسماد النانو . 